A rectilinear or Nodosaria-like Lituola, with an extremely labyrinthic subdivision of its chambers, is common in the Tertiaries of San Domingo, Malaga, and Tuscany (figured by Soldani), and occurs recent in the mud of the Abrolhos Bank, east of Rio Janeiro.

18. Lituolites difformis. Ann. Mus. v. p. 243, No. 2 ; viii. pl. 62. f. $13 a, b$; Hist. An. s. Vert. vii. p. 605 . No. 2 ; Lituola difformis, Tabl. Enc. Méth. pl. 466. f. $1 a, b$. "Fossil; Chalk, Meudon."

A small irregularly grown Lituola nautiloidea.

[To be continued.]

XXXIII.-On the Marginal Nerves of the Leaves of Mosses. By George Gulliver, F.R.S., Fellow of the Royal College of Surgeons of England, and Honorary Fellow of the Royal College of Surgeons in Ireland.

The term 'nerve' is here used for the leaf-rib, in the same sense as it has always been employed (though so inconveniently) by botanists, and without the least reference either to the function or to the structure of the very different and more important cords with the same name in the animal kingdom.

While so much attention has been paid to the mid-nerve of mossleaves, it seems singular that even the existence of the marginal nerves, identical in structure with the mid-nerve, has not been recognized by systematic writers in Britain. At least, I believe there is no notice of the kind in the classical works of Smith and Hooker, nor in the recent 'Bryologia Britannica' of Mr. Wilson; and as in this last excellent book the system of Bruch and Schimper is adopted, I presume the same remark will apply to their celebrated 'Bryologia Europæa,' which I have not yet seen. Moreover, in a cursory reference to M. Schimper's 'Recherches sur les Mousses' (4to, Strasburg, 1850), I could find no such mention of marginal leaf-nerves. Indeed, descriptive bryologists say " nerve excurrent," "nerve vanishing," and so forth, for the mid-nerve, as if there were no other nerve in a moss-leaf, as, no doubt, is most often, but by no means always, the case, independently of the well-known double nerve in certain genera.

This is the more remarkable, as the marginal nerves can be so easily demonstrated by very slight dissection under the microscope, while their course and structure will probably be found to afford good specific characters. Schleiden ('Principles of Scientific Botany,' p. 188, transl. by Dr. Lankester, 8vo. Lond. 1849) has depicted them in Mnium punctatum, and justly observes that the leaves of Mosses and their nerves merit a more thorough investigation than they have hitherto received. 
I have examined the marginal nerves in the leaves of a great number of Mosses, and in some instances have seen them extending from the very cells of the axis or stem to the point, or beyond the point, of the leaf-blade; and these nerves may generally be found when the border of the leaf is described as "cartilaginous" or " thickened," though their structure, being commonly a soft and juicy prosenchyma, has no relation whatever to the structure of cartilage, nor to the bryological definition of it-" a hard close texture, not tender and succulent."

The following extracts from my note-book will render it easy for the bryologist to examine these nerves, without the aid of a drawing, particularly as the kindness of $\mathrm{Mr}$. Mitten has made me sure of the identity of the species.

Atrichum undulatum. Dec. 1859. Very distinct marginal nerves from the stem to the point of the leaf, and $\frac{1}{1280}$ of an inch in diameter, the mid-nerve being fully thrice as large. The measurements in this and the following instances are made near the middle of the nerves.

Fissidens bryoides. Dec. 3, 1859. Marginal nerves very plain, $\frac{1}{2} \frac{1}{286}$ of an inch in diameter, while the mid-nerve is $\frac{1}{71} \overline{0}$.

Fissidens tamarindifolius. Dec. 23, 1859. Marginal nerves as distinct as in F. bryoides, and $\frac{1}{2460}$ of an inch in diameter, the mid-nerve being $\frac{1}{6} \frac{1}{6}$.

Mnium hornum. Jan. 1860. Marginal nerve $\frac{1}{800}$ of an inch in diameter, extending most plainly from the base to the apex of the leaf, and composed of about three rows of prosenchymatous cells remarkably distinct from the contiguous squarish or polyhedral parenchymatous cells of the leaf-blade.

Bryum capillare. Jan. 1860. Marginal nerves $\frac{1}{12} 50$ of an inch in diameter, scarcely distinguishable from the neighbouring cells of the leaf-blade, though portions of the nerve may be sometimes torn off, and it can be traced into the apiculus of the leaf. This leaf is a fair specimen of a connecting link between the presence and absence of a plain marginal nerve.

\section{XXXIV.-On some New Genera and Species of Mollusca from} Japan. By Arthur Adams, F.L.S., \&c.

\section{To the Editors of the Annals of Natural History.}

Gentlemen,

Tsu-Sima, Straits of Korea, 5th Dec., 1859.

In the course of our circumnavigation of the Sea of Japan, in H.M.S. 'Actron,' the dredge was sometimes put in requisition, and, in addition to a better acquaintance with the geographical distribution of marine life which was thereby afforded, 


\section{$2 \mathrm{BHL}$ Biodiversity Heritage Library}

Gulliver, George. 1860. "XXXIII.-On the marginal nerves of the leaves of Mosses." The Annals and magazine of natural history; zoology, botany, and geology 5, 298-299.

View This Item Online: https://www.biodiversitylibrary.org/item/19558

Permalink: https://www.biodiversitylibrary.org/partpdf/39840

\section{Holding Institution}

Natural History Museum Library, London

\section{Sponsored by}

Natural History Museum Library, London

\section{Copyright \& Reuse}

Copyright Status: Public domain. The BHL considers that this work is no longer under copyright protection.

This document was created from content at the Biodiversity Heritage Library, the world's largest open access digital library for biodiversity literature and archives. Visit BHL at https://www.biodiversitylibrary.org. 